China's Emerging Global Businesses 
Also by Yongjin Zhang

CHINA IN THE INTERNATIONAL SYSTEM, 1918-1920

CHINA IN INTERNATIONAL SOCIETY SINCE 1949

ETHNIC CHALLENGES BEYOND BORDERS (co-editor with Rouben Azizian)

POWER AND RESPONSIBILITY IN CHINESE FOREIGN POLICY

(co-editor with Greg Austin) 


\section{China's Emerging Global Businesses}

\section{Political Economy and Institutional Investigations}

Yongjin Zhang

Department of Political Studies

University of Auckland, New Zealand 


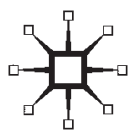

(c) Yongjin Zhang 2003

Softcover reprint of the hardcover 1st edition 2003 978-0-333-99934-9

All rights reserved. No reproduction, copy or transmission of this publication may be made without written permission.

No paragraph of this publication may be reproduced, copied or transmitted save with written permission or in accordance with the provisions of the Copyright, Designs and Patents Act 1988, or under the terms of any licence permitting limited copying issued by the Copyright Licensing Agency, 90 Tottenham Court Road, London W1T 4LP.

Any person who does any unauthorised act in relation to this publication may be liable to criminal prosecution and civil claims for damages.

The author has asserted his right to be identified as the author of this work in accordance with the Copyright, Designs and Patents Act 1988.

First published 2003 by

PALGRAVE MACMILLAN

Houndmills, Basingstoke, Hampshire RG21 6XS and

175 Fifth Avenue, New York, N.Y. 10010

Companies and representatives throughout the world

PALGRAVE MACMILLAN is the global academic imprint of the Palgrave Macmillan division of St. Martin's Press, LLC and of Palgrave Macmillan Ltd. Macmillan ${ }^{\circledR}$ is a registered trademark in the United States, United Kingdom and other countries. Palgrave is a registered trademark in the European Union and other countries.

ISBN 978-1-349-43333-9 ISBN 978-0-230-59961-1 (eBook)

DOI $10.1057 / 9780230599611$

This book is printed on paper suitable for recycling and made from fully managed and sustained forest sources.

A catalogue record for this book is available from the British Library.

Library of Congress Cataloging-in-Publication Data

Zhang, Yongjin.

China's emerging global businesses : political economy and institutional investigations / Yongjin Zhang.

p. $\mathrm{cm}$.

Includes bibliographical references and index.

ISBN 978-0-333-99934-7 (cloth)

1. Corporations, Chinese. 2. International business enterprises China. 3. Investments, Chinese - Government policy. 4. Structural adjustment (Economic policy) - China. 5. China - Commercial policy. 6. China - Foreign economic relations. I. Title. HD2910.Z43 2003

$338.8^{\prime} 8951-\mathrm{dc} 21$

2002035787

$\begin{array}{rrrrrrrrrr}10 & 9 & 8 & 7 & 6 & 5 & 4 & 3 & 2 & 1 \\ 12 & 11 & 10 & 09 & 08 & 07 & 06 & 05 & 04 & 03\end{array}$




\section{Contents}

List of Tables, Figures and Boxes

viii

Acknowledgements

$\mathrm{X}$

List of Abbreviations

xii

\section{Part I Revisiting the Economic} Internationalisation of China

1 Economic Reform and the Internationalisation of the State

Internationalisation: contested definitions

Economic reform and internationalisation

Internalisation and the internationalisation of the state

Summary

2 The Internationalisation of the Chinese Economy:

Empirical Evidence

Growth of foreign trade

Foreign direct investment

Loans from foreign governments and international organisations

Commercial borrowings

Other portfolio inflows

Capital outflows

International engineering and labour service trade

\section{Part II The Political Economy of China's Emerging Global Businesses}

3 Towards the Transnationalisation of Chinese Firms:

Policies and Debates

Understanding multinationals in the world economy

Initiating general and particularistic policies, 1979 to 1988

National economic development strategy and transnational operations: earlier debates 
Policy debates, 1989-92 and beyond 66

Institutionalisation of policy regimes and globalisation 72

$\begin{array}{ll}\text { Summary } & 80\end{array}$

4 China's Multinational Corporations: Then and Now 81

$\begin{array}{ll}\text { Transnational operations before } 1978 & 82\end{array}$

A new and modest start, 1978 to $1987 \quad 88$

Adjustments and growth, 1988 to $2000 \quad 95$

Outward investment from China since 1978: an overview 102

China's multinational corporations today: a profile 111

$\begin{array}{ll}\text { Summary } & 116\end{array}$

Part III The Transnationalisation of Chinese Firms: Institutional Investigations

5 CITIC: A Pioneer Chinese Multinational 125

$\begin{array}{ll}\text { CITIC today } & 127\end{array}$

Rong Yiren and the establishment of CITIC 129

Early transnational operations, 1979 to $1986 \quad 134$

Restructuring and expansion, 1987 and after 140

Towards a financial investment holdings conglomerate 148

$\begin{array}{ll}\text { CITIC Pacific } & 149\end{array}$

CITIC Australia $\quad 151$

$\begin{array}{ll}\text { Summary } & 156\end{array}$

6 Sinochem: Global Reach 159

$\begin{array}{ll}\text { Sinochem at its prime } & 161\end{array}$

Trading with a difference, 1979 to $1987 \quad 165$

Experimenting with transnational operations, 1988 to $1990 \quad 173$

$\begin{array}{lr}\text { Global reach } & 178\end{array}$

Towards a multinational trading conglomerate? 180

Sinochem's mid-life crisis 183

$\begin{array}{ll}\text { Summary } & 187\end{array}$

7 Shougang: Going Transnational 190

Shougang and economic reforms in China 192

$\begin{array}{ll}\text { First international businesses } & 197\end{array}$

From technology-seeking to technology-exporting 201

Deng Xiaoping and Shougang, $1992 \quad 204$

From Hong Kong to Peru 208 
Whither Shougang as a multinational corporation post-1995?

215

Summary

218

8 Conclusion

Notes

231

Bibliography

256

Index

275 


\section{List of Tables, Figures and Boxes}

\section{Tables}

2.1 Share of foreign-funded enterprises in China's exports, industrial output, and investment in fixed assets, 1990-99 29

2.2 Loans from foreign governments and international organisations to China, 1992-96

2.3 International bond issues by selected developing countries, 1985-90

2.4 China's international bond issues, 1991-94

2.5 China's issues of sovereign bonds, 1987-97 34

2.6 Long-term capital outflows from China, 1990-96 37

2.7 China's construction, engineering and labour service trade, 1991-2001

4.1 China's non-trade-related outward investment, 1979-88 91

4.2 China's large overseas investment projects, 1980-87 93

4.3 China's outward investment, 1991-95 98

4.4 China's inward and outward investment, selected years 104

4.5 China's outward FDI stocks (selected years) in comparative perspective

4.6 Geographical distribution of China's outward FDI stocks in comparative perspective

4.7 Transnationality of the largest Chinese TNCs in 1996 and the national average in comparative perspective

5.1 Assets, net assets and profit of CITIC, 1991-2000 128

5.2 CITIC's foreign and Eurobond issues, 1982-85 136

8.1 GNP per capita and NOI of China and the four Asian tigers, 1997

\section{Figures}

2.1 The growth of China's foreign trade, 1978-2001 26

2.2 Composition of China's exports, 1980, 1990 and $2000 \quad 27$

2.3 FDI flow into China, 1988-2000 28

2.4 FDI and foreign loans used by China, 1990-95 28

4.1 China's outward investment, 1991-2000 99

5.1 Growth of CITIC's assets and net assets, 1983-2000 128

5.2 Allocation of CITIC's assets, $2000 \quad 129$ 
5.3 CITIC's corporate structure, $2000 \quad 130$

5.4 CITIC Australia's corporate structure, $2000 \quad 153$

6.1 Sinochem's turnover, 1990-95 162

6.2 Breakdown of Sinochem's turnover, $1996 \quad 162$

6.3 Corporate structure of Sinochem, $1996 \quad 165$

6.4 Sinochem's trade volume, 1979-87 171

6.5 Sinochem's export of petroleum products, 1979-87 171

6.6 Sinochem's overseas subsidiaries, $2000 \quad 179$

\section{Boxes}

3.1 The MOFERT documents on outward investment 56

3.2 Government-specified requirements for the approval of outward investment

3.3 The bureaucratic control of China's outward investment $\quad 59$

3.4 Inhibiting factors for the transnationalisation of Chinese firms 


\section{Acknowledgements}

Writing a book is an intellectual journey, a personal and often formidable one. This is particularly true for me in writing this book. The idea was first conceived in the mid-1990s when I was completing another monograph on China in International Society since 1949. I literally bumped into a large number of disaggregated data on China's outward investment activities, and was told bemusing tales of Chinese companies' overseas adventures. Impulse as much as intellectual curiosity was the inspiration for the conception of this project. Little did I expect, however, that it would have been such a challenging and demanding one, accompanied by enormous enjoyment and enrichment as well as by occasional frustrations and irritation. If in completing this project, I have had to stretch myself into a number of unfamiliar territories and have had a testing experience, it is also enriching and enabling. It challenges me to extend my scholarship and learning. It enables me to come to a better understanding of that fundamental economic transformation that China is experiencing today, which I have put down on paper to share with readers of this book.

An intellectual journey would never have been completed without supportive and inspiring companions. I am deeply indebted to a large number of individuals and institutions that have helped me with my interviews and research in China as well as in other parts of the world over the years. I would like to acknowledge my thanks in particular to Bian Yongzhuang, Feng Xiaoming, Guo Shuqing, Natasha HamiltonHart, He Jiacheng, Kang Yongping, Lin Ye, Pi Shenghao, John Ravenhill, Shao Binhong, Shi Yutang, Song Xinning, Wang Haijun, Xie Duo, Yu Yongding, James Xiaming Zhan, Zhang Jijing, and Zhang Xiaojin. My debt to many of them goes beyond the intellectual.

I owe many debts of gratitude to a number of institutions, in particular to the United Nations Conference on Trade and Development (UNCTAD) for granting me access to its library and allowing me to conduct interviews at its headquarters in Geneva, and to the Centre for Asian Studies of the University of Hong Kong for sponsoring me as a Visiting Scholar while I was doing my research in Hong Kong. The University of Auckland provided initial financial assistance to kick-start this research project. The Department of International Relations, Research School of Pacific and Asian Studies of the Australian National Univer- 
sity, where I was a Fellow between 1999 and 2001, provided a supporting environment and research grant for the completion of this book. I would like to register my gratitude to both these institutions here. At Palgrave Macmillan, I am grateful to my commissioning editors Nicola Viinikka and Amanda Watkins for managing the publication of this book, and to Guy Edwards for seeing through its production.

My ultimate debt is, as always, to my family, who offered unfailing moral and indispensable logistical support throughout this journey. I dedicate this book lovingly to my wife Shanping and to my daughter Jessie, who has grown up into a university student at Cambridge while I was completing this project. 


\section{List of Abbreviations}

$\begin{array}{ll}\text { ABC } & \text { Agricultural Bank of China } \\ \text { ADB } & \text { Asian Development Bank } \\ \text { ADR } & \text { American Depository Receipts } \\ \text { APEC } & \text { Asia-Pacific Economic Cooperation } \\ \text { BOC } & \text { Bank of China } \\ \text { CCB } & \text { China Construction Bank } \\ \text { CCP } & \text { Chinese Communist Party } \\ \text { CIB } & \text { CITIC Industrial Bank } \\ \text { CIS } & \text { Commonwealth of Independent States } \\ \text { CITIC } & \text { China International Trust and Investment Corporation } \\ \text { CNAC } & \text { China National Aviation Corporation } \\ \text { CNIFP } & \text { Central North Island Forestry Partnership } \\ \text { CNOOC } & \text { China National Offshore Oil Corporation } \\ \text { CNPC } & \text { China National Petroleum Corporation } \\ \text { COFCO } & \text { China National Cereals, Oils and Foodstuffs Import and } \\ & \text { Export Corporation } \\ \text { COPRI } & \text { Comision de Promocion de la Inversion Privada } \\ \text { COSCO } & \text { China Ocean Shipping Company } \\ \text { COSTIND } & \text { Commission for Science, Technology and Industry for } \\ & \text { National Defence } \\ \text { CPPCC } & \text { Chinese People's Political Consultative Conference } \\ \text { EIU } & \text { Economist Intelligence Unit } \\ \text { ENR } & \text { Engineering News Record } \\ \text { FDI } & \text { Foreign Direct Investment } \\ \text { FEER } & \text { Far Eastern Economic Review } \\ \text { FOTIC } & \text { China Investment and Trust Corporation for Foreign } \\ \text { GATT } & \text { Economic Cooperation and Trade } \\ \text { GDP } & \text { General Agreement on Tariff and Trade } \\ \text { GFCF } & \text { Gross Domestic Product } \\ \text { GITIC } & \text { Gross Fixed Capital Formation } \\ & \text { Corporation } \\ \text { GNP } & \text { Gross National Product } \\ \text { IBRD } & \text { International Bank for Reconstruction and Development } \\ \text { ICBC } & \text { Industrial and Commercial Bank of China } \\ \text { ICI } & \text { Imperial Chemical Industries } \\ & \end{array}$




$\begin{array}{ll}\text { IDA } & \text { International Development Association } \\ \text { IDP } & \text { Investment Development Path } \\ \text { IISI } & \text { International Iron and Steel Institute } \\ \text { ILO } & \text { International Labour Organisation } \\ \text { IMF } & \text { International Monetary Fund } \\ \text { IPO } & \text { Initial Public Offer } \\ \text { ITICs } & \text { International Trust and Investment Corporations } \\ \text { LME } & \text { London Metal Exchange } \\ \text { M\&A } & \text { Merger and Acquisition } \\ \text { MIA } & \text { Multinational Investment Agreement } \\ \text { MNC } & \text { Multinational Corporation } \\ \text { MNE } & \text { Multinational Enterprises } \\ \text { MOFERT } & \text { Ministry of Foreign Economic Relations and Trade } \\ \text { MOFTEC } & \text { Ministry of Foreign Trade and Economic Cooperation } \\ \text { NICs } & \text { Newly Industrialising Countries } \\ \text { NIEO } & \text { New International Economic Order } \\ \text { NOI } & \text { Net Outward Investment } \\ \text { OECD } & \text { Organisation for Economic Co-operation and } \\ & \text { Development } \\ \text { PBOC } & \text { People's Bank of China } \\ \text { PICC } & \text { People's Insurance Company of China } \\ \text { PLA } & \text { People's Liberation Army } \\ \text { PRC } & \text { People's Republic of China } \\ \text { RMB } & \text { Renminbi } \\ \text { RMRB } & \text { Renmin Ribao (People's Daily) } \\ \text { SAFE } & \text { State Administration for Foreign Exchange } \\ \text { SAIC } & \text { Shanghai Automobile Industry Corporation } \\ \text { SCRES } & \text { State Commission for Restructuring the Economic } \\ & \text { System } \\ \text { SEG } & \text { Shenzhen Electronics Group } \\ \text { SEZs } & \text { Special Economic Zones } \\ \text { SGNEC } & \text { Shougang-NEC } \\ \text { SINOCHEM } & \text { China National Chemicals Import and Export } \\ \text { SINOPEC } & \text { Corporation } \\ \text { SOE } & \text { China Petroleum and Chemical Corporation } \\ \text { SPC } & \text { State-owned Enterprises } \\ \text { SWB } & \text { State Planning Commission } \\ \text { TNCs } & \text { Service of World Broadcast } \\ \text { TNEs } & \text { Transnational Corporations } \\ \text { TVEs } & \text { Transnational Enterprises } \\ \text { Town and Village Enterprises } \\ & \end{array}$


xiv List of Abbreviations

$\begin{array}{ll}\text { UN } & \text { United Nations } \\ \text { UNCTAD } & \text { United Nations Conference on Trade and Development } \\ \text { UNDP } & \text { United Nations Development Programme } \\ \text { UNIDO } & \text { United Nations Industrial Development Organisation } \\ \text { UNIPEC } & \text { China United Petroleum Corporation } \\ \text { UNTCMD } & \begin{array}{l}\text { United Nations Transnational Corporation and } \\ \text { Management Division }\end{array} \\ \text { USAC } & \text { US Agri-Chemical Co. Ltd } \\ \text { WTO } & \text { World Trade Organisation }\end{array}$

